\title{
Personalities of Brands Using Social Media Efficiently
}

\author{
Özgül Dağlı, Üsküdar University, Turkey
}

\begin{abstract}
Brand value means combination of constituents consisting of its functional benefit, emotional benefit, personal benefit and commitment supports, and brand characteristics has an important place among these constituents. Success and role of social media in reflecting characteristics of brands is an inarguable truth. In this study, the brands in social media preferred the most by young consumers that frequently uses social media are analyzed and personality characteristics of these brands are addressed. Findings of the study contain an evaluation on personality characteristics of the top three most preferred brands as Turkcell, Turk Telekom and Mavi Jeans. In the evaluation on these 3 brands, Aaker's (1997) scale where he associates brands with human-specific personality characteristics and used as the most applied scale in assessing brand personality has been used as the assessment tool. Finding of the study present personality profiles of the most popular GSM and fashion brands of social media.
\end{abstract}

Keywords: Social Media, Brand Personality, Brand Identity 


\section{Introduction}

In today's communication world where digital revolution and transformation is constantly discussed and the intensive competition each brand has to experience, one of the key aspects brands apply for differentiation is stories they attribute to their brands and characteristics embraced in structuring brand image. Brand experiences of consumers confront us directly related with personality characteristics of brands reflected on them and the brand perception. It is now expected from each brand to become perceptively different and tell its personality characteristics for communicating its story to consumers through right expressions and right channels (Uztuğ, 2008, p.115). Brand has personality because people tend to associate human attributes with brands. Brands are often consumed in a social setting where a brand's personality creates brand differences that can satisfy people's self-expression and social needs (Xu et al. 2016, p. 436). People use brands to define how young or old they are, how masculine or feminine they are, how upscale or downscale they are, and how different or similar to members of their social groups. Social media is an effective marketing communications tool to express both personality and other important reflections of consumers lifestyle.

The brand personality characteristics assisting communicating stories of brands are the subject of this study. The ways for taking place in social media as one of the most important means of communication succeeded in taking place in our lives shapes the study method (Park et al. 1986). In the study, the first considered issue is the most used social media environments. It was also expected from the participants in AB SES group to indicate the brands they like and follow the most in social media environments such as Instagram, Facebook and Twitter. According to the results, these brands are Turk Telekom, Mavi Jeans and Turkcell.

\section{Theoretical Background}

\section{Definition of Brand Personality and its Importance for Consumers}

It has become almost impossible in current competitive conditions to create concrete, functional and physical differences between products and concordantly, these personality characteristics of brands and all kinds of concrete and abstract elements are added to the brand value (Aaker, 2014; Keller, 1993, p.5). Despite traditional ones, brands adopting new marketing trends as the main theme of this study are the brands sweeping in the path of 
success which correctly follow new trends, adopt digital transformation and succeed in establish the right connection with its consumers through a right channel and right story. At this point, brand personality is in the forefront among the concepts perceived for brand value constituents such as quality, brand awareness, brand loyalty, brand identity, brand positioning and brand association. As personality is important for individual existence, it is also equally important for existence of a brand (Tosun, 2014, p.94-95; Low and Lamb, 2010). Considering brand personality with regards to consumer behavior, it is observed in the brand image or brand identity studies in the literature that it is tried to establish a parallel structural relation between the personality characteristics of people and personality characteristics of brands for assessing personality of brands. Conducted studies prove this. (Aaker and Biel, 1993; Torlak and Kurt, 2005; Aaker, 1997, Dölarslan, 2012; Barrick and Mount, 1991;).

Brand personality characteristics are attributed to brands in a similar way to the consumer experience fields and it is ensured that the experience is more delightful and catching by presenting a brand as a person. Actually, social media presents multi-directional, interactive and advantageous environments for brands to create a field of experience. We can say that consumers feel pleasure establishing connections with brands or identifying brands with their personalities and like establishing a connection between the personality of a celebrity or role model with their personalities. Brand personality can be perceived as in direct interaction with personality characteristics of a role model using that brand; it can also be perceived by indirectly associating it with physical characteristics of a product, brand name, logo, price, point of sale and advertising method (Toprak and Kjurt, 2005, p.16). Concordantly, we see that the studies conducting brand personality analysis and scales developed for assessing brand personality have also been established based on personality characteristics of people.

\section{Social Media and Its Role and Importance for Brand Personality}

Today, the channel which can establish the strongest and the easiest bond between a brand and its target group is social media. Social media is a place where people exist in accordance with their fields of interest and expectations and reflect their own tastes, requests, ideas and objections. As brand personality makes sense for a non-living thing, it is quite important among all things we say (Aaker, 1991). Before, presenting brands in social media, brand personalities should be studied. Because, social media does not go through a single channel and content management is needed. While, conducting personality studies, you should think 
holistically, include interactive design and design innovatively in accordance with marketing trends. In this sense, the thing to be done by brands is to establish the right profile in social media, pay attention to cover photos, videos and language and give fast responses to comments by considering crisis management. In addition to this, following current developments and implementing a successful content management focusing on interactive designs are also important (Yener, 2013, p.90-91).

As mentioned by Uğur Bat1, now there are several brand trends and even the eight of them is "Humanistic brands trend". (2015, p. 107-108.). Humanistic brands trend can be considered as one of the important marketing trends describing humanistic characteristics provided for brands by brand personality characteristics. Social media, internet and other digital environments confront us as means of communication expanding their domains fast in the entire advertisement sector and communication field and assist in establishing bonds between target groups and brands within the context of "humanistic trends". In their brand structuring processes, the brands of our age frequently include social media contents and digital designs to become a love brand in Brandlove rank. (Bat1, 2015, p.352). Moreover, several sector professionals indicate the digital transformation of advertising and recent studies on advertising draw attention to significance of this issue and even its efficiency as much as traditional advertising channels (also some opinions on much higher efficiency) through digital data. In this study, brand personalities of some of the most used brands of digital environments qualified as successful in social media are evaluated and the human characteristics used by these brands with the most popular media contents to structure their identities are seen.

\section{Method of the Study}

\section{Purpose of the Study}

The general purpose of this study is to describe the personality characteristics of the brands considered by the young population between 18-25 ages living in Istanbul as the most efficient brands in using social media through the Brand personality aspects scale developed by Aaker. Answers for the following questions were searched for fulfilling this purpose;

- What are the SES group and demographic characteristics of participants of the study?

- What are the mostly preferred social media environments of the participants? 
- What are the first three brands considered successful in social media by the participants?

- What is the rank by considering the personality characteristics of these 3 brands?

- Is there any meaningful gender-based difference in brand personality evaluations?

\section{Research Model and Data Collection Process}

This study is a qualitative research in survey model. Survey method was used as the data collection tool. The survey is a qualitative research technique where opinions, recommendations and experience of participants are shared on a particular subject. The first 7 questions in the survey were asked for determining the demographical and socio-economical statuses of the participants. In the $7^{\text {th }}$ question, all social media websites were listed and it was asked if they use them or not. In the $8^{\text {th }}$ question, the brands they follow in social media were asked. In the $9^{\text {th }}$ question, personality characteristics identified in brand personality scale of Aaker were questioned by means of 5-point likert scale (Barrick and Mount, 1991). From this scale, 36 personality characteristics suitable for Turkish brands were included in the survey. The brand personality scale used in this study consists of 5 main aspects in the literature and sub-factors used for assessing these main aspects. These five main aspects are Sincerity, Enthusiasm, Sufficiency, Versatility and Fierceness. These characteristics were tested for assessing these aspects (cited in Özgüven and Karataş, 2010, p.144).

\section{Sincerity:}

Humble: Family oriented, small town-dweller, affordable price

Honest: Sincere, real, ethical, thoughtful, compassionate

Dignified: Original, unique, unageing, classic, old-fashioned

Cheerful: Emotional, friendly, sympathetic, happy

\section{Enthusiasm:}

Brave: trend, thrilling, extraordinary, ostentatious, provocative

Alive: Dashy, young, lively, sociable, adventurous

Huge Imagination: Unique, humorous, surprising, artistic, entertaining

Current: Independent, modern, innovative, aggressive

\section{Sufficiency:}

Reliable: Hard-working, secure, efficient, trustworthy, attentive

Smart: Technical, corporate, serious 
Successful: Leader, confident, influential

\section{Versatility:}

Superclass: Ravishing, handsome, assertive, versatile

Charming: Feminine, smooth, sexy, kind

\section{Fierceness:}

Suitable for outdoors: Manly, western, vigorous, athletic

Tough: Strong, powerful, intelligent

Survey has been conducted by face-to-face interview technique. As it takes much time and expensive, 150 survey participants were determined by random sampling method from various departments of Uskudar University and selected from young people volunteered in participating the survey.

\section{Validity and Reliability of the Study}

Scale validity related with the validity of the survey is ensured as it is a survey used as a grand personality assessment tool developed by David Aaker in 1997 and used in several other studies. Survey data was entered into the SPSS package software and frequency analyses were conducted. Reliability analyses were conducted for 36 factors of each brand. Considering the scale reliability, Cronbach Alpha values were found 0.921 for Turkcell, 0.88 for Mavi Jeans and 0.906 for Turk Telekom and these values show that the scale is reliable.

\section{Findings and Comments}

\section{Demographic Findings}

According to the survey results, $50 \%$ of participants are female and $50 \%$ are male. The age range is in between 18 and 25 . Number of family members is 4 with the highest $70 \%$. Education level of young participants is at $80.7 \%$ graduate and $18.7 \%$ undergraduate.

\section{Socio-Economic Findings}

According to survey results, $56 \%$ of householders of participants have graduate level education while $39 \%$ high-school level education. $60 \%$ of householders of participants are salaried employees and 33\% have their own businesses. Considering total income of families of survey participants, it is seen $26 \%$ is around $2300-3300 ; 49.3 \% 3300-4300$ and $24.7 \%$ 
higher than 4300 Turkish Liras. According to this, SES distribution is as in Chart 4 (https://www.slideshare.net/hmehme/ses-2012?next_slideshow=1).

\section{Chart 1 Social Economic Class}

\begin{tabular}{|ll|r|r|r|r|}
\hline & Frequency & Percent & $\begin{array}{c}\text { Valid } \\
\text { Percent }\end{array}$ & Cumulative Percent \\
\hline Valid & 39 & 26,0 & 26,0 & 26,0 \\
& A & 111 & 74,0 & 74,0 & 100,0 \\
& B & 150 & 100,0 & 100,0 & \\
\hline
\end{tabular}

\section{Social Media Usage}

The participants were asked about the social media environments they use the most. According to their answers; Instagram, Facebook, Twitter, YouTube and Foursquare took the top 5 in the list.

Chart 2 Instagram Usage

\begin{tabular}{|l|r|r|r|r|r|}
\hline & & & Vali & \\
& & & & \\
& & & Cumula \\
& & Frequenc & Perce & Perc & tive \\
nt & ent & Percent \\
\hline Valid & YES & 141 & 94,0 & 94,0 & 94,0 \\
& NO & 9 & 6,0 & 6,0 & 100,0 \\
& Total & & & 100, & \\
& 150 & 100,0 & 0 & \\
\hline
\end{tabular}

Chart 3 Facebook Usage

\begin{tabular}{|c|c|c|c|c|c|}
\hline & & $\begin{array}{c}\text { Frequen } \\
\text { cy }\end{array}$ & $\begin{array}{c}\text { Perce } \\
\text { nt }\end{array}$ & $\begin{array}{c}\text { Valid } \\
\text { Perce } \\
\text { nt }\end{array}$ & $\begin{array}{l}\text { Cumula } \\
\text { tive } \\
\text { Percent }\end{array}$ \\
\hline \multirow[t]{3}{*}{ Valid } & YES & 136 & 90,7 & 90,7 & 90,7 \\
\hline & NO & 14 & 9,3 & 9,3 & 100,0 \\
\hline & Total & 150 & 100,0 & 100,0 & \\
\hline
\end{tabular}


Chart 4 Twitter Usage

\begin{tabular}{|c|c|c|c|c|c|}
\hline & & Frequency & Percent & $\begin{array}{l}\text { Valid } \\
\text { Percent }\end{array}$ & $\begin{array}{c}\text { Cumulative } \\
\text { Percent }\end{array}$ \\
\hline \multirow[t]{3}{*}{ Valid } & YES & 109 & 72,7 & 72,7 & 72,7 \\
\hline & $\mathrm{NO}$ & 41 & 27,3 & 27,3 & 100,0 \\
\hline & Total & 150 & 100,0 & 100,0 & \\
\hline
\end{tabular}

Chart 5 YouTube Usage

\begin{tabular}{|c|c|c|c|c|c|}
\hline & & $\begin{array}{c}\text { Frequen } \\
\text { cy }\end{array}$ & $\begin{array}{c}\text { Perce } \\
n t\end{array}$ & $\begin{array}{c}\text { Valid } \\
\text { Perce } \\
\text { nt }\end{array}$ & $\begin{array}{c}\text { Cumulati } \\
\text { ve } \\
\text { Percent }\end{array}$ \\
\hline \multirow[t]{3}{*}{ Valid } & YES & 141 & 94,0 & 94,0 & 94,0 \\
\hline & NO & 9 & 6,0 & 6,0 & 100,0 \\
\hline & Total & 150 & 100,0 & 100,0 & \\
\hline
\end{tabular}

Chart 6 Foursquare Usage

\begin{tabular}{|c|c|c|c|c|c|}
\hline & & $\begin{array}{c}\text { Frequen } \\
\text { cy }\end{array}$ & $\begin{array}{c}\text { Perce } \\
\text { nt }\end{array}$ & $\begin{array}{c}\text { Valid } \\
\text { Perce } \\
\text { nt }\end{array}$ & $\begin{array}{c}\text { Cumula } \\
\text { tive } \\
\text { Percent }\end{array}$ \\
\hline \multirow[t]{3}{*}{ Valid } & YES & 60 & 40,0 & 40,0 & 40,0 \\
\hline & NO & 90 & 60,0 & 60,0 & 100,0 \\
\hline & Total & 150 & 100,0 & 100,0 & \\
\hline
\end{tabular}

\section{Brands Followed the Most in Social Media}

According to survey results, 129 from 150 participants follow Mavi Jeans brand with 86\%, 93 participants follow Turk Telekom - Avea brand with $62 \%$ and 94 participants follow Turkcell brand with $62.7 \%$. 


\section{Personality Analyses of the First 3 Brands}

Turkcell Brand Personality Analyses Frequency Table (First 10)

\begin{tabular}{|l|l|}
\hline Answers & Percentages \\
\hline A Hard Working Brand & $82,67 \%$ \\
\hline A Smart Brand & $82 \%$ \\
\hline A Successful Brand & $80 \%$ \\
\hline A Merry Brand & $78 \%$ \\
\hline A Modernistic Brand & $77,34 \%$ \\
\hline A Self-Confident Brand & $76,67 \%$ \\
\hline A Free Brand & $74,67 \%$ \\
\hline A Dynamic Brand & $71,34 \%$ \\
\hline A Modern Brand & $72 \%$ \\
\hline A Well Apparent Brand & $71,34 \%$ \\
\hline
\end{tabular}

Turk Telekom Personality Analyses Frequency Table (First 10)

\begin{tabular}{|l|l|}
\hline Answers & Percentages \\
\hline A Smart Brand & $75,34 \%$ \\
\hline A Successful Brand & $74,67 \%$ \\
\hline A Hard Working Brand & $73,34 \%$ \\
\hline A Merry Brand & $72 \%$ \\
\hline A Self-Confident Brand & $70,67 \%$ \\
\hline A Well Apparent Brand & $69,34 \%$ \\
\hline A Family Oriented Brand & $68,67 \%$ \\
\hline A Modernistic Brand & $66,67 \%$ \\
\hline A Virtuous Brand & $66 \%$ \\
\hline A Brave Brand & $65,34 \%$ \\
\hline
\end{tabular}

Mavi-Jeans Personality Analyses Frequency Table (First 10)

\begin{tabular}{|l|l|}
\hline Answers & Percentages \\
\hline A Successful Brand & $85,34 \%$ \\
\hline A Well Apparent Brand & $84,67 \%$ \\
\hline A Smart Brand & $84,67 \%$ \\
\hline
\end{tabular}




\begin{tabular}{|l|l|}
\hline An Elegant Brand & $84 \%$ \\
\hline A Free Brand & $84 \%$ \\
\hline A Merry Brand & $81,34 \%$ \\
\hline A Creative Brand & $81,34 \%$ \\
\hline A Hard Working Brand & $81,34 \%$ \\
\hline A Modern Brand & $80 \%$ \\
\hline A Western Brand & $79,34 \%$ \\
\hline
\end{tabular}

According to survey findings and considering percentages of 3 brands; Turkcell was assessed by 18-25 age AB SES group participants respectively as hard working, smart and successful; Turk Telekom respectively as smart, successful and hard-working and Mavi Jeans respectively as successful, well apparent and smart.

\section{Gender-Based Evaluation of Personality Analyses}

\begin{tabular}{|c|c|c|c|c|c|c|c|}
\hline & & $\begin{array}{c}\text { An Old } \\
\text { Fashion } \\
\text { Brand }\end{array}$ & $\begin{array}{l}\text { A Merry } \\
\text { Brand }\end{array}$ & $\begin{array}{c}\text { A Dynamic } \\
\text { Brand }\end{array}$ & $\begin{array}{l}\text { A Hard } \\
\text { Working } \\
\text { Brand }\end{array}$ & $\begin{array}{l}\text { A Young } \\
\text { Brand }\end{array}$ & $\begin{array}{c}\text { A Smart } \\
\text { Brand }\end{array}$ \\
\hline \multirow[t]{5}{*}{ Gender } & $\begin{array}{l}\text { Pearson } \\
\text { Correlatio } \\
n\end{array}$ & ,179* &,$- 182^{*}$ &,$- 178^{*}$ &,$- 239^{* *}$ &,$- 198^{*}$ &,$- 176^{*}$ \\
\hline & $\begin{array}{l}\text { Sig. (2- } \\
\text { tailed) }\end{array}$ & ,028 & ,026 & ,029 & ,003 & ,016 & ,031 \\
\hline & $\begin{array}{l}\text { Sum of } \\
\text { Squares } \\
\text { and Cross } \\
\text { products }\end{array}$ & 17,000 & $-12,000$ & $-11,000$ & $-15,500$ & $-13,047$ & $-9,500$ \\
\hline & $\begin{array}{l}\text { Covarianc } \\
\text { e }\end{array}$ &, 114 &,- 081 &,- 074 &,- 104 &,- 088 &,- 064 \\
\hline & $\mathrm{N}$ & 150 & 150 & 150 & 150 & 149 & 150 \\
\hline
\end{tabular}

According to the analysis based on the survey, Mavi-Jeans brand shows a positive relation $(\mathrm{p}=0,028<0,05)$ at 0.05 significance level in likert scale questions for the answer of "An Out of Fashion Brand". It shows a negative relation at 0.05 significance level for the answers of "A Good-Humored Brand", "A Lively/Cheerful Brand", "A Young Brand" and "A Smart Brand". It shows a negative relation at 0.01 significance level $(p=0,003<0,01)$ for the answer of "A Hard-Working Brand". It shows a positive relation at 0.179 significance level 
for the answer of An Old Fashion Brand, 0.182 for the answer of Good-Humored Brand, 0.178 for the answer of A Lively/Cheerful Brand, 0.239 for the answer of A Hardworking Brand 0.198 for the answer of A Young Brand and a negative relation at 0.176 significance level for the answer of A Smart Brand.

\section{Results and Conclusion}

Brand value is determined in accordance with its personality and bond established with its consumers. Brand value is determined by characteristics such as identity and personality and this makes it the first remembered brand in retrieval process. Brand personality has been evaluated in several studies based on several cultural elements. In this study, the evaluation is conducted based on Turkish culture by considering the first most preferred 3 brands in Social Media.

The study results indicate that if the personality analyses of the brands active in social media and considered successful with regards to their contents is taken into consideration, they generally show a successful identity and efficient stand as "hardworking", "smart" and "good-looking". Sometimes, in this age of digital transformation where borders between the virtual and real world become vague, showing such a successful personality characteristic in social media is very important for brands and considering the competitive conditions, it becomes an extremely significant for creating difference by becoming distinguished among others. These results also show that a consistent and rich content, an attractive design and an efficient social media language are necessary for brands to continue their existence and success in social media environment. Furthermore, it should be noted that the brands considered successful in digital environment are recognized as long as they are "good looking", "smart" and "creative". 


\section{References}

-Aaker, David A (1991). Managing Brand Value: Capitalizing on the value of a brand name, The Free Press Yay. ABD.

-Aaker David A.; Alexander L. Biel (1993). Brand Equity\&Advertising: advertising's role in building strong brands,_Lawrence Erlbaum Ass. Yay, ABD.

Aaker, J., (1997), "Dimensions of Brand Personality” Journal of Marketing Research, 34(3), Aralık, s. 347

Anbang Xu; Haibin Liu; Liang Gou; Rama Akkiraju; Jalal Mahmud; Vibha Sinha; Yuheng $\mathrm{Hu}$; Mu Qiao (2016). "Predicting Perceived Brand Personality with Social Media", Proceedings of the Tenth International AAAI Conference on Web and Social Media (ICWSM 2016), USA: 436-445.

Barrick, Murray R. Ve Michael K. Mount (1991), “The Big Five Personality Dimensions and Job Performance: A Meta-Analysis," Personnel Psychology, 44: 1-26.

Bati, Uğur (2015). Marka Yönetimi: vazgeçme çağında "yüksek sadakat markaları yaratmak”. Alfa Yay. İstanbul.

Dölarslan, Emre Şahin (2012). "Bir Marka Kişiliği Ölçeği Değerlendirmesi” Ankara Üniv. SBF Dergisi, Cilt.67, no.2. 1-28.

Keller, Kevin Lane (1993), “Conceptualizing, Measuring, And Managing Customer-Based Brand Equity “, Journal of Marketing, , Vol. 57, no. 1.

Low, George S.; Charles W. Lamb Jr (2000), “The Measurement and Dimensionality of Brand Associations”, Journal of Product \&Brand Management,_vol.9, no:6, , s.350-368

Özgüven, N., Karataş, E., (2010), “Genç Tüketicilerin Marka Kişiliği Algılamalarının Cinsiyete Göre Değerlendirilmesi”, Süleyman Demirel Üniversitesi Sosyal Bilimler Enstitüsü Dergisi, Sayı 11, s. 140

Park, C. Whan, Bernard J. Jaworski Ve Deborah J. Maclnnis (1986), "Strategic Brand Concept-Image Management," Journal of Marketing, 50 (4): 621-35.

Torlak, Ömer; Cevahir Kurt; (2005); “Kola Markası Kişiliklerinin Üniversite Öğrencileri Tarafından Algılanması", İşletme Fakültesi Dergisi, Cilt 6, Sayı 2: 15-31

Tosun, Nurhan Babür (2014). Marka Yönetimi, 2. Bask1, Beta Yay. İstanbul. Uztuğ, Ferruh (2008), Markan Kadar Konuş:Marka İletişim Stratejileri,_Kapital Medya A.Ş. yay., Ankara. 
VURAL, Z. BERİL AKINCI; MİKAİL BAT, (2010). "Yeni Bir İletişim Ortamı Olarak Sosyal Medya: Ege Üniversitesi İletişim Fakültesine Yönelik Bir araştırma” Journal of Yasar University, 20(5):3348-3382.

YENER DURSUN, (2013). "Marka Çağrışım Unsurlarının Marka Kişiliği Üzerine Etkisi” Electronic Journal of Vocational Colleges”, May. 89-103.

\section{Internet Resources}

SES 2012, MediaCom presentation. (https://www.slideshare.net/hmehme/ses2012?next_slideshow=1) 27.09.2017. 